\title{
The "Minister of Production in the Collectivist State" as a Third Way of the Market: China Between Ethics and Growth
}

\author{
Catia Eliana Gentilucci \\ University of Camerino, Camerino (MC), Italy
}

\begin{abstract}
This paper proposes a comparison between the Chinese social-economic system of today and the economic planning system theorized by Enrico Barone in 1908, which described in his famous paper "The minister of production in the collectivist state”. The work stems from a critical reflection on the premises of the capitalist market system. From Adam Smith to J. M. Keynes (included), economists have identified in traditional capitalist models (search for maximum profit, economic efficiency, free competition system) the best economic system, universally implementable, feasible and infallible in democratic capitalist contexts. In the history of economic ideas have always been clear gap between the "capitalist system" and the "collectivist system". The choice of a government had to fall back on one or on the other system. The first considered "good", the second considered “bad” for economic growth. Times since September 11, 2001, however, seem to have debunked the myth of capitalism as the only model of democratic growth: Asia and China have given the world a lesson in humility. China has shown that although not being a democratic country could developed a robust and highly competitive economic model that has weakened the pillars of the western capitalism. China through Confucianism and Taoism has been able to establish the new global economic laws: low labour costs, low prices, mass production of low quality with a mixed mercantilist philosophy which is unknown to the Western world: the silent, smooth, radical trade expansion. As in a game of dominoes, China has been able to drop the capitalism safeties and America had to bow its head and agree to no longer be the only great power in the international scenario. But the peculiarity of this work is not only to define the root causes of China's success in the West; also reflects the fact that an Italian economist (Enrico Barone), in 1908, predicted analytically and developed a theoretical system very similar to that of China nowadays, between capitalism and collectivism (a third way of the market). The Asian culture has developed a market system that has proven to be accommodating to the needs of the capitalist market and to grasp the development opportunities that the same Western capitalism has offered.
\end{abstract}

Keywords: capitalism, China, collectivism, confucian state, individual Taoism, economic growth

\section{Prologue}

This paper proposes a comparison between the Chinese nowadays social-economic system and the economic planning system theorized by Enrico Barone in 1908 and described in his famous paper "The minister

Catia Eliana Gentilucci, Ph.D. in History of Economics Ideas, Assistant Professor, University of Camerino.

Correspondence concerning this article should be addressed to Catia Eliana Gentilucci, University of Camerino, Piazza Cavour, Camerino (MC) 62032, Italy. E-mail: c.gentilucci@yahoo.it. 
of production in the collectivist state".

The article had international academic confirmations, rivers of words have been written on its clarity, its analytical sustainability, and on its brilliance and originality of the proposed solution in identifying a position of equilibrium of second best set in a planned context, although considered, by Barone himself, "different from the scientific collectivism” (Barone, 1908, p. 183) ${ }^{1}$.

The work now being proposed is the result of a reflection that highlights how Enrico Barone, predicting the time, has drawn up a theoretically perfect system and strongly close to a reality that in 1900 was not predictable (in fact, the Asian model that was revealed to the world in the last decade represents a quantum shift that has no historical precedent).

The comparison, therefore, between the current Chinese system and planned system theorized by Barone, a century ago, today is only feasible because some similarities between the two systems are aligned.

But if coincidences do not happen by chance, a curiosity has to puzzle the reader's mind: Did Enrico Barone know the text of Sun Tzu's military strategy which, written in 490 BC, is now the basis of the Western management literature and the Chinese economy?

As it is well known:

(1) The precepts of the work of Sun Tzu The Art of War, inspired by Confucius, were offset by a Chinese philosophy and seem to reflect, even today, the relational and socio-economic strategy of the Chinese world (Mini, 1998);

(2) Barone has been involved, since 1887, in military strategy, in military history and in military sociology. The text of Sun Tzu might, therefore, have been read by Barone since it has been translated into French in 1782 (and it was present in the library of the War College in Turin, where Barone had studied and taught The Art of War in 1888 and 1889 ), and into English in 1910 by Lionel Giles;

(3) As we shall see, Barone seems to be guided by the logic of military strategy, similar to those of Sun Tzu, when he discusses issues related to the war economy.

Seem, therefore, to be the conditions to argue that for Barone, accustomed to apply strategic military thinking to economy, could be guided by the precepts of Sun Tzu to explain a planned market system (due to either political choices or needs of war) that aims for economic growth.

But then it opens another issue, since it is also known that:

(1) Enrico Barone knew the paper "On war” (1832-1837 posthumously) by Carl von Clausewitz (another enlightened strategist of the nineteenth century of Prussian training) and that he shares his principles;

(2) And that the traditional literature on military strategy poses the strategic thinking of Carl von Clausewitz at odds with the thought of Sun Tzu.

\section{Introduction}

Enrico Barone has gained international fame thanks to his writing that brilliantly synthesizes the lessons of general economic equilibrium given by Leon Walras and Vilfredo Pareto.

The Minister of Production, therefore, precious and pure stone of the scientific contributions of the History

\footnotetext{
${ }^{1}$ About the scientific collectivism, Barone refers to the marxist type which provides for the nationalization of all productive factors.
} 
of Economic Thought, was praised for its unparalleled contribution to the reasoning, synthetic and academic, about the general economic equilibrium.

It was, in fact, considered a pure and crystalline demonstration of how the Walrasian and Paretian theory of general economic equilibrium can find proof of correctness analysis.

The literature has, however, neglected the other important aspect of economic analysis: its ability to describe the relationships that affect the real context.

In this writing where we intend to give voice to this latter aspect: the potential of the work of Barone to explain the functioning of a real collectivist system.

The inner peculiarity of the work of Barone is that he considers impossible to plan, a priori, the production structure in order to ensure the system to achieve the maximum collective welfare, since, for Barone, it is not possible to define a priori the level of the marginal productivity for factors of production that ensures equality between costs and revenues.

In particular, although for Barone, it is possible but very difficult to solve the equations of equilibrium at the table, considering the factors of production given and without considering the technical variability, it will be, however, "even inconceivable that we can make a priori the determination of factors of production in such a way as to satisfy the condition of the minimum cost of production” (Barone, 1908, p. 204).

In Barone's writing, it claimed the suggestion to reach a third way of the market of second best (compared to the first best solution of perfect competition) that stands between free market and scientific collectivism that has interesting similarities with the current system in Asia.

We will see that Barone puts as foundations of his model an ethical behaviour of individuals and institutions that are close, respectively to the Taoist's scheme and to the Confucianism's scheme.

In essence, for this writer, Barone's work is Timeless and Geographicless, it is, precisely, a theoretical construct but seems to well fit the historical reality of the Asian markets called "socialist market economy", founded by Deng Xiaoping in the 1980s, and officially implemented by China in 1993 (Kornay \& Qian, 2009)².

It is obvious that Barone when he thought the figure of the Minister of Production could not be inspired by the Asian market at that time, that was not for sure what we know today as closed and backward within its borders. Although Barone, even not directly aware of the Chinese culture, seems to have perception of the contradictions and puzzles of the Chinese philosophy, as well as reveals in his article "Cu-Nan-Sien" of 1900 which are decrypted on the events of the Boxer Rebellion.

In essence, aware of the controversy on the schedule that has occupied the minds of Lange, Dobb, Hayek, purpose of this work is not to enter into the merits of that debate, but to ascertain any possible points of contact between the mathematical-economic system of Barone and the planning system adopted by China in the 1980s that has implemented a reform called Third Way of the Market often decrypts as the "New Long March, where, the word 'Long March’ indicates the great difficulties in the transition from administrative socialism to a socialist

\footnotetext{
2 The "socialist market economy" is a term by which Deng Xiaoping called the set of economic reforms that led the Republic of China to privatize a large part of the state-owned industries. The coexistence of private and public was, according to Deng Xiaoping, the economic ideology that China should follow to successfully open up to foreign markets. Deng Xiaoping summed up the idea of the "socialist market economy" said in its "No matter whether the cat is black or white, as long as it catches mice". That is one goal of the Chinese economy to "grab" the opportunities that globalization posed to the West and China in this way is freed from the ideological rigidity of its predecessors, among them the figure of Mao Zedong.
} 
market economy” (Wu, 2009, p. 43).

\section{Philosophical Fundaments: Confucian State, Taoist Individual}

Before entering the analysis of how Barone's work is adequate to explain the development of the Asian markets it seems appropriate to say a few words about the philosophical foundations of Chinese Taoism and Confucianism (Rosser \& Rosser, 2004).

Taoism founded by Lao Tzu, was built in the same historical period of Confucianism (in the first millennium BC) and, along with this, it forms the intellectual capital of China until now.

As Confucius and Lao Tzu being contemporaries, the same historical situation of decline of the Chou dynasty (which ruled for six centuries now, and had lost the momentum for reform of the early kings), pushing the two founders to evoke golden time in which there existed the simplicity and the natural order of the Tao, for Lao Tzu; justice and power of the emperors of the past, for Confucius (Sideri, 2011).

But while Confucianism deduced the role models to return to the moral virtues of ancient kings, Taoism endured harsh criticism for the conduct of the emperors pointing in those virtues the mischief of the primitive of Tao, founded on the spontaneity of the natural order.

In summary, the Tao is an abstraction that shows the universal law of nature, the spontaneous way of being and behaviour of the Universe, the natural universal balance; the Tao teaches us the moral of "no action", which demands respect of the natural order that is spontaneous and harmonious.

If it develops an attitude in the individual as selfish and individualistic, the emperor will have to remember him that his origin is in the Tao and inaction.

It is pretty obvious that how this philosophy is close to that of the invisible hand of Adam Smith and the consequent theory of laissez faire (McCormick, 1999, pp. 331-341; Dorn, 1998, pp. 131-146).

Without traces the long history and abundant literature on the invisible hand, it is interesting for our purposes to recall that Enrico Barone, analyzing the economic determinism (according to which the phenomena follow a predefined path by natural law) recognizes to man a certain "will” given by the knowledge of natural laws of the social evolution that would allow him to make the right choice, making his behaviour more consistent with the efficiency as dictated by the natural order.

But returning to China, we said that Confucianism is contemporary to the opposite Taoist philosophy even lives with it permeating the whole modus operandi of the Chinese social system.

Confucianism, taking example from the ancient emperors (their strength and military power, their wisdom and their effective and efficient conduct), locates in the state the guarantor and interpreter of the laws of nature. So if in a simple society (an isolated village where there is no use of machines) the market is spontaneous and Taoist; in a more complex society, the state must take care of the market, as institutions such as the emperors of Confucius, have awareness of laws of natural order and can apply them to the collective system.

Individuals, following the Taoist ethic, with devotion they will accept state laws, participating to achieve the ultimate goal of social growth and adapting themselves to the dictates of state planning. Collective interests are higher than the individual ones.

The obvious differences between Asian system and the Western system are that, in this last one, it is not well defined the line between "action for individual purpose” and "action for public purpose”. 
In the capitalist economic literature, there is a clear clash between the two dimensions: first, the confidence in the laws of free market, the efficiency and the rationality of individual choices; and second, the awareness of market failure requiring the intervention of the state into economy.

The eternal comparison, in Western capitalism, between the system's ratio and the inability to achieve economic equilibrium situations, is resolved case by case as defined by state intervention in the field of public choices of long and short term. In the Asian system, however, the controversy is resolved a priori: the state programs and defines the objectives of short and long term inspired to economic growth, while the individual rationally and consciously adapts its behaviour to the economic achievement of the state's goal. The state, as in the period of Confucius, is not involved a posteriori, but a priori planning the road to pursue.

Without forcing our interpretation, it can be argued that this duality (Confucian state and Taoist individual) is present in the reflections of Barone (Gentilucci, 2006).

In fact, referring to the state, it argues that there will be a planned system in which a bureaucrat, who knows the natural laws of free market, organizes production so as to achieve the economic system the equilibrium condition of second best.

While, referring to individuals, it argues that a planned system will be auto-legitimated if individuals share the attitude of first putting the collective goal to the individual goal (in a Taoist way) conforming to the decisions of the Minister in production and in distribution "set up on some social and ethical criteria” (Barone, 1908, p. 182).

For Barone, in fact, the discipline required in an individual is one that "addresses all the faculties of the soul and intellect to achieve what is in the thinking of those who are higher up than us" (Barone, 1900a) consideration that strongly resembles the Taoists precepts.

That is in the model of Barone, the Minister is a Confucian who applies virtues of efficiency and of desire for "greater welfare", while individuals are Taoists who accept those rules by virtue of faith, as it seems to happen in China today.

And that is the fundamental condition of its undisputed economic rise on the international scene.

\section{The Art of War}

Barone, therefore, seems to recall, even if unconsciously, the Taoist and Confucian principles to explain how it should work a planned economic system.

But in the opinion of this writer that similarity is not accidental but due to the fact that Barone was a scholar of military affairs and knew the theory of warfare, so it could not translate his military attached reasoning to economic reasoning. So as in Chinese philosophy are evident influences of the precepts of Sun Tzu in economic strategies.

At the time of Enrico Barone, there were two lines of military thinking: the Western of Carl von Clausewitz and the Asian of Sun Tzu. The two approaches are contrasted: the Prussian strategist believes in the power of force to implement the plan of attack, while Sun Tzu says the power of "deception”” to disorient the enemy and make him harmless.

But what trend is the military reasoning of Barone close to?

\footnotetext{
${ }^{3}$ The Dao (or Path) is that attitude that allows the individual to pursue his goal. So in the event of a war: "If you are capable you have to show to be incapable, if you are active you need to show to be inactive. When you are close you have to give the impression of being distant and even when you are away to already be close. You try the enemy making him feel ahead and crush him pretending to be confused”. In Sun Tzu: The Art of War.
} 
If we are fairly certain that he knew "On war" by Carl von Clausewitz, we can not be so sure that he did not know the precepts of Sun Tzu, contained in the booklet The Art of War, as they have been translated into French around 1750 .

Barone also knew the peculiarities of Chinese culture, as demonstrated in his paper $\mathrm{Cu}$-Nan-Sien (and in his article in the Gazzetta Piemontese the same year) in which he states:

Mysterious antithesis are in Chinese soul, not easy to explain by a European, because ignorance of that language it is for him an insurmountable barrier to penetrate in their true mind; nor it is enough the interpreter because through his translation, the most delicate nuances of their thoughts and their feelings are slipping. (Barone, 1900, p. 492)

Barone in Lessons of Military Art writes:

Some writers have claimed to reduce the military strategy of a few absolute simples. We believe that by doing so they followed a false path. Military Art, as art, has no absolute principles, but maxims that has come from experience: such maxims are numerous and can not be, therefore, crystallized in a few diagnostic statements. (Barone, 1888, p. 10)

And it is quite plausible to argue that when Barone cites "maxims are the result of experience" does not refer so much to Carl von Clausewitz as "On war" is divided into hundreds of pages, but it is more likely that Barone refers to a booklet similar to that one of Sun Tzu, where in about 5,000 lines he synthesized and crystallized the principles of the successful Asian philosophy.

Barone was informed about events in the round of his time, the many themes of socio-economic, with versatile mind, are a highlight. So we can assume that he had knowledge, direct or indirect, of the precepts of China on the war (which are, in fact, summed up in aphorisms that capture the most utilitarian and rational aspect of individual behaviour).

In Sun Tzu's strategic thinking, the commander should not exalt the heroic action that will guarantee him eternal glory; but exploit the potential inherent in the present situation and identify and bring maturity to those elements that will be favourable to him.

Sun Tzu based his view of the conduct of the war on the idea that a good commander must act slowly, subtly, through marginal changes that slow down the process of action so as not to make it obvious.

The appeal to this devious behaviour emerges in the text of Barone when he describes the method by which the Minister, acting attempts, can guess the combination of inputs to be the best way to reach the highest level of collective well-being (who will not coincide with the Paretian optimum but with a Second Best solution).

While in Western strategic thinking of von Clausewitz, the good commander is preparing a theoretical plan to implement quickly in the battlefield to reach the win.

In the logic of Chinese, actions are imperceptible, are intangible and are part of a slow transformation, thin, silent (and therefore almost deceptive because it is not immediately obvious), but effective.

Clausewitz would appeal to the metaphor of the chameleon to indicate how the strategy has to adapt to events, with frank and direct changes; Sun Tzu, instead, the metaphor of the slow flow of water. In the military strategy handed down by Sun Tzu the single-action is acting in a micro-system, having the goal to win and defeat the opponent, defeat that is imposed by the coldness of rational calculation.

This strategy is palpable in the Chinese economy of today and can be identified in the strategy outlined by Barone in the Minister of Production, as a necessary tactic to make sure that the Minister can achieve his purpose. 
This attitude of acting by taking small steps to avoid giving evidence of our own actions is close to the method of determination of general economic equilibrium called "trial and error" of the auctioneer; and the acting of the capitalist who through marginal adjustments tries to optimize his choice.

Even if the reference of acting is not for marginal changes in the theory of war of Barone (but it is, instead, as is known, in his economic theory) there are elements of Barone's philosophy of war that are similar to those exposed by Sun Tzu.

So for example the argument that the conquest of a territory does not correspond to the submission sake of his people, but to control national resources and to establish a collaborative relationship (including respecting their culture and religion) to be able to exploit the national resources (Barone, 1911) still applied tactics by the Asian market in the economic war to the West.

Therefore Barone, in this context, seems to have acquired from von Clausewitz the idea that the conduct of the commander must be sincere and determined on the battlefield; but, inspired by Sun Tzu and declaring his disagreement to von Clausewitz, Barone said that the conqueror state must gain the confidence of the conquered people to exploit the national local resources with greater freedom.

If we try to sum up the foregoing regarding the influence of Sun Tzu and Carl von Clausewitz in the strategic thinking of Barone, we can reasonably argue that Barone, as he has shown in his economic writings, does not arise in favour of one or the other school of thought because, as being eclectic, he prefers to propose new interpretive hypotheses that stand between a thesis and antithesis.

\section{The Minister of Production: Between Planning and Collectivism}

Barone was an Italian economist known for being liberal and linked to the marginalist school of thought. His writting of 1908, which was added to Hayek (von Hayek, 1935; Sorrentino, 2011), has given him international fame for having studied "as liberal” the economic planning.

In short, Barone also in a collectivist system a rational Minister (who knows the laws of the free market and by those he is inspired) may apply an economic process efficiently planned.

Barone for the establishment of a system where there is a state coordination of the production process it is feasible also because, although he shared the principles of neoclassical theory, he was not an uncompromising liberal.

Enrico Barone opened his famous paper by stating:

In order to produce in a collectivist state, there are two issues at all different from each other. One is: will it be useful for some capital to become collectively owned and production be socialized? The second is this one: how in a collectivist system the production should be ordered? We can discuss the second question any court other than that it means the first. And it is, in fact, a study on the second question that I propose to do. (Barone, 1908, p. 161)

And again in the Principles of Economics (Barone, 1908a, p. 678), he wrote:

The science of economics has never dreamt to say that the state should remain with his hands to his waist, trusting that the initiative of individuals ensure themselves (...), the economics has never dreamt to say that there are no cases in which the economic interest of the individual may conflict with other collective interests, and therefore should be subject to these, with the inevitable limitations, by the state, to the full freedom of individual himself.

And also in the Principles (Barone, 1908a, p. 680), he said: 
It is also explained that the State intervention to improve the productivity of agriculture, in a field that is of economic activity, in which the actions are always slow and sluggish. There is nothing presumptive against such an intervention: The verdict depends only on the good that it knows how to do or on the evil that it knows how to avoid.

Barone, therefore, had planned to offer his readers an organic reflection, and not affected by value judgments, the functioning of a planned system.

The amazing news is that the idea that the Minister is well illuminated to know the rules of the natural order and to bring them to market, by meeting the criteria of distribution shared by the community (Barone, 1908, pp. 183-184), and that, moreover, the economic categories of the free market are not invalidated ${ }^{4}$.

\section{The Minister of "Distribution"}

The Minister suggested by Barone is an institutional representative of a social system to population control in which some means of production are owned by the State, and that a Minister may coordinate (or as Barone writes "may manage") the business of production and consumption, based on a determined distribution formula shared by the ethic existing system.

Barone (1908, p. 182) stated:

Some funds are still property of individuals (e.g., those that give personal services): let $M, N$... in the number of $l$. the capital that have become collectively owned by the state (for example, capital investments and land) let $S, T$... in the number of $l$. The Minister of Production has to solve the problem of combining these individual and collective services in order to provide the best comfort to his directors. He has studied the issue and broke it resolved on the basis of a certain distribution formula that is been established by the community on certain ethical and social criteria, which is not our purpose entertain ourselves directly with.

The novelty of Barone's argument based on the fact that the Minister can not define (as impossible to practice) the relationships between demand and supply of services and goods, such that occurring equivalence between costs and revenues to ensure the economic general balance, since such relations of equality should be determined voluntarily by the market, the Minister has got an instrument of coordination of the economy the possibility to modify, by trial and error, the distribution of income.

Barone (1908, pp. 186-187) wrote: “This series of equivalencies exists; but it is useless to seek it weary” and again: "The Minister may only make use of the great freedom that he has got to change the supplements of individual distribution”.

While the level of consumption and hence savings is controlled through the "deferred consumption”, given by a casual "premium rate" decided by the Minister.

Barone argues, therefore, that one can not exclude the possibility to establish a planned economy, but the economy must be based on the laws of free market for determining the level of production and demand.

Accordingly, the planning of the market lies in determining a distribution formula and an interest rate that changes, by trial and omissions, real variables to obtain a balance that will not, however, the corresponding to the Paretian optimum (first best solution).

The Baronian reference of proceeding by "trials" of the Minister, to locate the plane of consumption and production more suitable for real-world context is not so much a reminder of the marginalist theory (since the

\footnotetext{
${ }^{4}$ Barone argues that the sale of the land in a collectivist state is not cancelled due to the different soil fertility.
} 
opening of his work he claims to want not to use the Paretian indifference curves because metaphysical), but the method of Sun Tzu of the assessment to infinitesimal degrees of changes in real variables compares to a strategic predefined plan.

The planned model of Barone is the paroxysm of a system working in perfect competition. In fact, he says:

Many believe they have refuted collectivism, when they have shown that certain propositions of Marx or others, contain errors and contradictions. The refutation of these propositions has not, after all, some value, because, even without falling into those errors and contradictions one can easily imagine an economic system that carries the (collectivist) spirit of the Marxist system. (Barone, 1908)

It is possible, therefore, to achieve a planned economic system based on the mechanism of laws of the capitalist market. Such a system requires, to be implemented, a skilful mind, able to make the foundations of the more traditional economic theory at system.

The first aspect to be considered in the model of Barone is the non-application of the indifference curves. He applies the concept of demand, supply and production costs and assumes as given: the level of prices, consumer tastes and the amount of capital available in the system. While he assumes that the Minister can change the weightings of manufacture and distribution formula.

The economic system proposed by Barone involves the construction of the "marginal and average condition" (equality between marginal revenue and marginal cost, average cost equals the price) that will determine the level of the shadow price. In the economic process there is only one maximum "collective", given by the "sum of the products and services consumable" (Barone, 1908, p. 173).

If extra profits are made (due to the difference between the level of the shadow price and level of market price) someone will improve his condition (and someone else will decrease it accordingly); and this will hinder the achievement of the maximum collective because, according to Barone, also removing from the firsts to give to the seconds it is not restored the optimum condition.

For Barone, in fact, the difference between the firsts (the benefit ones) and the seconds (the disadvantaged ones) is that the net improvement will be less compared to that inflicted on the seconds, due to the violation of the competitive equilibrium conditions (minimum costs of production, prices equal to production costs) (Barone, 1908, p. 174).

In summary, for Barone, if one wants to benefit an economic class, it is better to act directly at the distribution level (through a "charge distribution”) (Barone, 1908, pp. 186, 193, 202) because, with the same advantages of the privileged class, worsening imposed on the disadvantaged class is less than that the latter would suffer from the change of the free market conditions.

The Minister shall intervene, therefore, into the distribution of income following an ethical and social framework fitting the support to public economy. He writes: "The indirect distribution is rigid and can not follow certain ethical and social criteria with all the freedom that is given by direct distribution, giving appropriate values to the charge of distribution” (Barone, 1908, p. 193).

For Barone, (given that the Minister of Production could, theoretically, detect the production plan that minimizes costs and the pattern of consumption that maximizes utility) by applying the equations of free competition, it will be possible to get a production level of balance even if "different" from that obtained under perfect competition. 


\section{The Third Way of the Market: Market Coordination and Second Best}

The Baronian hypothesis that the production factor of work remains the property of individuals involves a matter not to be underestimated, as applies if the private property of certain inputs, the market where the Minister acts, it is not a socialist-collectivist market (as that one of the Soviet Union or that one of Yugoslavia), but it is a "market socialism", that is a third way of the market (similar to what exists in China today), which in a coordinated manner the rules of capitalist system are applied and in which there are economic categories into the capitalist market. It is a hand that from "invisible" it becomes "institutional visible".

Barone writes: "It will be useful for some capital to become collectively owned and production to be socialized"; that there is a centralized coordination "market coordination", implemented by China in the 1980s. The pattern of "market coordination" has elements of perfect competition and elements of planning in it, and, following Barone's work, can be represented in Table 1.

Table 1

Microeconomic and Macroeconomic Level

\begin{tabular}{|l|l|}
\hline \multicolumn{2}{|c|}{ Microeconomic level } \\
\hline Supply & Production plans are programmed by the Minister of Production \\
\hline Demand & The level of consumption is decided by the families while respecting the production plans \\
\hline Coefficient of production & Defined by attempts by the Minister of Production \\
\hline Marginal condition and average condition & Defined by the market mechanism of supply and demand \\
\hline Equilibrium price & It is a consequence of the market mechanism of supply and demand \\
\hline & \multicolumn{2}{|l|}{ Macroeconomic level } \\
\hline Consumption level & Influenced by the range of interest and forced saving \\
\hline Investments level & Adjusted by try by the Minister of Production through the interest rate \\
\hline National product & Adjusted from the market (second best solution) \\
\hline Income distribution & Defined by the Minister of Production \\
\hline
\end{tabular}

Recalling the considerations of Petretto (1982, pp. 145-167), we can see that Barone from "forerunner of the modern theory of efficient allocation of resources" had identified that a planned system could achieve economic efficiency if it gave space to an iterative procedure for finding contemporary the Paretian optimum and the shadow prices, associated to it, and if it provides a criterion of compensation in the income distribution (like Kaldor) ${ }^{5}$, that we have already seen, how Barone identified it in a "direct transfer" made by the State to economic categories.

These conditions are closely related to the Second Theorem of Welfare, which provides, in fact, an interference State compensation in a context of "collective system".

In fact, Barone says that in the collective system as a given Paretian optimum: "it is supported by a competitive balance and by a particular redistribution of resources”.

As it is known, the rate of growth in China over the past decade was around $10 \%$, it is difficult to determine whether this rate corresponds to the Paretian optimum in an absolute sense; while it is easy to observe that there is

\footnotetext{
${ }^{5}$ Therefore, an optimal choice in terms of allocation (max output) is not necessarily also ensure the maximum welfare. An attempt to overcome the limit of legal precepts, and reframe the analysis of collective choice is preferable if it generates an increase in real income that benefits from a part of the community in order to compensate those affected by the order regardless whether the compensation takes place.
} 
no impediment to the hypothesis that the rate of Chinese growth is one of the best among those in the corresponding period in the rest of the world; and that, therefore, even if the Chinese economic structure has not reached the Pareto optimum in an absolute sense, it has certainly got a solution that is one of the best solutions of second best.

According to Barone, if a planned system is based on decentralization, between consumption and production (as in China today), the shadow prices, defined by the system, indicate a situation of equilibrium (II Theorem of Welfare).

Obviously, if the shadow price is a result of the natural process of law of the market and the natural order, which leads naturally to the Walrasian equilibrium, we can not exclude that this order should be supreme in Asian markets, which through the Taoist ethics can achieve a level of shadow price even lower than that achieved in the West, thanks to low labor costs (Taoist ethics, in fact, does not require social demands) and the intensive use of labor.

The hypothesis that the Asian shadow price is lower than the Western one, along with the assumption that the average level of prices in the West is greater than the Asian one, it makes chines products very competitive, as it can be seen in Figure 1.

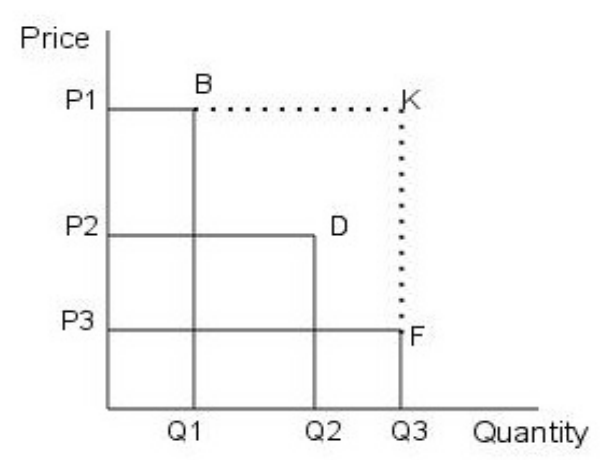

Figure 1. Shadow price.

Where by definition: $P 3$ represents the shadow price of China; $P 2$ the Western shadow price; $P 1$ the average price of western markets.

Although the comparison between the two levels of the shadow price of Chinese and Western leads to the conclusion that the rectangle P3-F-Q3-0 (Revenue of China) has a smaller area compared to the rectangle P2-D-Q2-0 (Revenue of West) in a describing sense the two areas are overlapping, since both describe a situation in which the costs are equal to revenues.

What is important to note in the chart is that the Asian markets sell in the world market (national and international) the amount $Q 3$ at a price ranging between $P 1$ and $P 3$ (since $P 1$ is the price at which the West is willing to buy the goods necessary to its needs); so the Asian markets can achieve an income equal to the area $P 1-K-F-P 3$, which would allow them a double-digit growth of its gross domestic product (as it is happening for several years).

The writer reiterates that the Asian miracle is due to Taoist ethics of individuals who are projected to achieve a common good as a priority over the individual one; and to the behavior of the Confucian state that, by applying the virtues of Confucius (wisdom and rationality) is able to control the desire for profit of individuals and to 
ensure production levels, with low costs and high revenue flow, resulting in an increase of the national product. In this way, China has an advantage in international competition because it enjoys the difference between the western and the inner shadow prices, also because it can obtain high revenues from the sale of its products in the capitalist market that offers the same goods at higher prices.

\section{“Guanxi” and Ethics of Market Coordination}

At a good look the planned system of Barone comes close to the "Cooperative Shareholding System” (Zeng, 2005, pp. 183-208; Nathan, Hong, \& Smith, 1999) of China in the 1990s that was applied to the rural center of Shanghai.

Discounting Barone's statement to the Chinese system, we can observe that in this context there is a redistribution of resources taken by the People's Republic of China that benefits or workers or entrepreneurs depending on the objectives fixed in the short-run by the system. The shareholding cooperative system was introduced in the 1990s when China started to implement a policy of privatization for the productive activity.

In particular, the System Shareholding Cooperatives, as its name suggests, is a hybrid of capitalism and socialist cooperative institution.

This form of market is set up on norms of distributive justice that have three characteristics: first, those employed in this system are also owners of the land and, therefore, responsible for management, and secondly, the distribution of profits is aimed primarily at work and is decided at government level, and thirdly, the system is designed to increase the collective wealth. For Vermeer (1999) the shareholding cooperatives system is a mechanism that promotes the independence of management, financial responsibility and promotes a sense of responsibility and leadership.

These objectives are closely linked to the idea of Asian democracy (Sulpasso, 2010).

According to Wu Jingliand we have democracy:

Eliminating the surviving feudal influences; eliminating the phenomenon of over-concentration of power; concentration of all power in Party committees, the power of the "Party committees" themselves is often in the hands of a few secretaries, especially the first secretaries, realizing: separation of "Party leadership" from "Government administration"; and separation of "Government administration” from "Enterprise management”; and expanding the inner-party democracy and people’s democracy. (Wu, 1998, p. 434)

Considering the various economic categories in the Chinese system, it is necessary to make a basic premise that some Chinese authors have pointed out.

According to Aoki (Masahiko, 2001; Bowles \& White, 1994), to illustrate the cognitive model that expresses the socio-economic context of China, it is necessary to enter the already known models of free market model and of collectivism in order to convert these models into an alternative model that expresses a relationship between culture and institutional change.

As it is explained by Pillath (2009, p. 121):

Understanding cognitive models requires an hermeneutic methodology that identifies meanings and possibly converts those into other systems of meanings that are shared in a scientific community. That is, the simple comparison between two states (such as "planned economy" and "market economy") is not sufficient in order to understand true path-dependencies of institutional change. Methodologically, this amounts to a reinstatement of historical methods in economies. 
And again:

This is especially true for ambiguous states of institutional change, where competing cognitive might support old and new institutions. Further, language is especially important for the "translation" of cultural phenomena into the conceptual framework of the scientific observer.

According to Pillath, the institutional change in China is defined as "ambiguous states of institutional change" which implies that there are two fundamental forces.

The first force is, however, dominant, even if it respects the principles inherent in the second force. As if to say, like Barone, the political superstructure must comply with the trends of the social structure to ensure that the first is entitled. The change in the institutional model should be done by following the natural evolution of the social context, to ensure that there is no social revolution which is necessary for the government to adapt to the changing of economic forces that reflect the needs of social classes.

On the other hand, the social structure itself can be shaped by institutional change, the important thing is that the two forces complement each other.

Similar reasoning is performed by those who argue that China is following a "third way of the market way of economy”: in which the concept of free market and the concept of collectivism open up to an economic category that includes them in a synergistic way.

The institutional design together with the culture result in a force compensation which marks the path of institutional change.

Thus, for example, the revision of the concept of socialism in China dates back to the period of Mao Tse-Tung when it began to reflect that to have a government of manageable economy it was more appropriate to create a decentralized economic system (but still tied to the political summit) (Wu, 2005) where it is recognized the right of private property.

But in this perspective, the concept of "Chinese private property” expresses different contents than the West:

The traditional concept of property in China never supported the absolute property rights familiar in the Western world. Individual property was conceived as a relational category in two senses: first, property belongs to the family, in that the individual owner is only a temporary caretaker who is obliged to increase its value for the coming generations; and, second, individual property was perceived as being embedded in a web of social relations in the village, which was a major obstacle to the emergence of land markets in China. Instead, a complex system of tradable and embedded lease-rights emerged, especially in south-eastern China, in which the village and the individual farmer were maintained as fundamental social units, but the legal owners were sometimes several levels apart in a chain of sub-leasing contracts. (Herrmann \& Pillath, 2009; Chow, 1994)

As Xiaobo Hu has claimed, land ownership is embedded in a dense network of social obligations that distort the economic category of property rights as understood in the West. Private property in China is interwoven with a dense network of social obligations, called "Guanxi”, that from subjective rights it becomes a commitment to the community to improve the property granted in private management.

The network of "Guanxi”6 (Yongshu, 2003) is considered ethical because it is shared by all and conforms to the common sense of distributive justice: "Land ownership is regularly embedded into a thick network of social

${ }^{6}$ The "Guanxi" is the determinant key of relations between companies and also involves social relations based on the exploitation of capital. 
obligations and is part and parcel of fundamental of livelihood and distributional justice” (Hu, 1998, p. 337; Tsang, 1998, p. 68); and the civil liability which includes birth control to prevent an overpopulation that would affect the interests of the entire community.

From Figure 2 we can see that the mix between the Institutional Program (the privatization of land, which was the foundation of capitalist development of the West) and the Confucian culture (which does not exclude a market-making profits in order to realize collective profits) creates a network of relationships between individuals (the "Guanxi”), which is the foundation of a market system in the middle between "capitalism” and "collectivism" (the third way of the market). The collectivist aspect is supported by the public and also moral liability of the individual towards the community. This sense of public and moral responsibility is missing in the capitalist economy of the West and leads to, exacerbating the pursuit of maximum personal profit, making economic agents compete with each other and making them not cooperative and not united. The "Guanxi" is a strong bond for the market and for state and collective goals. The "Guanxi" led the growth of China into the world as well as the lack of a sense of social cohesion in the West led to the tightening of the market and the loss of the common growth.

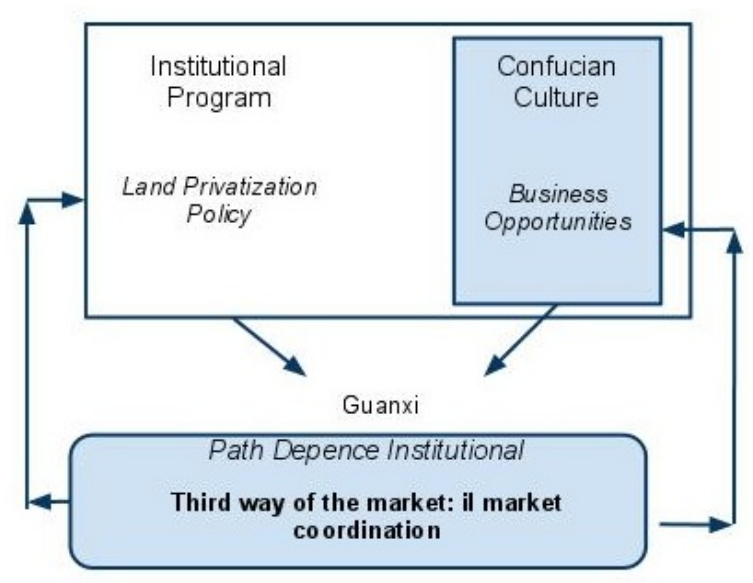

Figure 2. Conomic and social structure of relations.

The emblematic factor of the distance between the concept of ownership in China and the West is that the first identifies the owner of a parcel of land as the "temporary guardian" who has the social burden to raise the value of the property for future generations.

It is clear that this kind of property implies a freedom in the economic management of the asset (which has the primary purpose of increasing the value of the asset itself); but this is a collective responsibility that weighs on the temporary guardian of the land and that it binds him to community in a dense network of social obligations. In this respect, it cannot be accepted the argument put forward by Dorn (2001) for which: because China is privatizing the economy we have to expect a westernization of its system which, the author continues, appears to be the only way for a sustainable development.

Dorn's thesis is not entirely uncontroversial, because Chinese philosophy is so far from the West that does not make sense to assume that an economic category, even having the same name, it expresses the same situation. Privatization in China means, of course, not to use the freedom of land ownership, but to make the production 
decisions of the individual toward the collective needs through a chain of sub-leasing of property that provides for a "business-private" use of the land only for productive purposes or urbanization (Jing, 2001).

The twenty-first century China's reform of Deng Xiaoping, therefore, is based on the consideration that: the reform could only be an overall transition toward a market economy but it includes, among other changes, a shift away from the predominance of bureaucratic coordination towards the predominance of market coordination (Rosser \& Rosser, 2004a, p. 431) and that, as we have seen, seems to be close to the eclectic market system theorized by Barone as an alternative to the socialist system.

We have reaffirmed the great significance for the Asian system that everyone feels part of an indivisible whole and to it devote his actions.

We have also argued that it is possible to find the same relationship between private and public in the analysis of Barone, which shows that the collective need is primary comparing to individual need.

Barone had this insight when he explains that in a collectivist system, given an ethical system shared by the community, it is possible to obtain a Paretian optimum level supported by a competitive balance and by a particular distribution of resources (II Theorem of Welfare).

And to achieve this objective the conditions are linked to clearly defined ethical assumptions, may be questionable in the Western world: birth control; the use of vouchers to address the consumption of the domestic demand toward its own products; the choices of the planner on how to distribute the income having as objective economic success.

In the opinion of the writer, the People's Republic of China is actively managed to achieve a socio-economic mechanism that has no historical precedent: a collective ethical system in which everyone acts according to a well-defined path of freedom that leads to the common achievement of growth for the country; a system, in short, in which all together creates the whole because individuals, like termites in a termite mound, part of a collective plan aimed to achieve a common goal: the country's economic growth to become a superpower.

\section{Baronian Theoretical System and the Chinese System}

From a sociological point of view, the market coordination is a set of parties whose interests are related to joint to a target system, which means that as per a collective need, every person has an interest in all subjects meeting that need.

In the National Development and Reform Commission (NDRC) of 2010, issued by the Commission for Economic Development of the National Assembly of the People's Republic of China, it can be read that the organs involved with coordination of the labor market must "monitor (daily) the macroeconomic framework analyzing the performance of the national security, balance of trade, economic policy management, coordinate and direct the economic activities to economic performance such as choice of target system".

Pushing towards a more direct comparison between the content of the writing of Barone and the content of the ideas of economic planning of the Chinese NDRC, interesting similarities emerge, such as shown in Table 2.

\footnotetext{
${ }^{7}$ In the 1990s, this rural model was applied to the small and medium enterprises resulting to the phenomenon of "Susan model". Susan is characterized by the following steps: rural industrialization: strong interdependence between rural and city, the establishment of collective farms with intensive labour TVE (township and village enterprises) that are driving the development; opening of industrial parks that enable foreign capital; transformation of the rural industrialization.
} 
Table 2

Conditions at the Foundation of the Baronian System and the Chinese System

\begin{tabular}{|c|c|}
\hline on System & National Development and Reform Commision del 2010 \\
\hline ween goods and ser & $\begin{array}{l}\text { Step } 3 \text { of the NDRC: Synthesize and analyze the financial and tax situation and } \\
\text { formulate pricing policies to control the consumption of certain important } \\
\text { values, observe and evaluate the effects of price policy, monitoring the effects } \\
\text { of increasing taxation; control the external debt situation of China and promote } \\
\text { the equilibrium of the balance of payments. }\end{array}$ \\
\hline \begin{tabular}{|l|} 
The real ones are planned variable: \\
- Control of production factors \\
- Control of interest rates (which affects \\
consumption decisions, and then forced savings) \\
\end{tabular} & $\begin{array}{l}\text { Step } 5 \text { of the } 2010 \text { NDRC: Plan configurations and identify key productivity c } \\
\text { investment assets to be applied to the entire society; study investment project } \\
\text { of national and foreign capital; monitor the level of national consumption. }\end{array}$ \\
\hline Allowing the market to & $\begin{array}{l}\text { Step } 1 \text { of the NDRC, 2010: Formulate an integrated strateg } \\
\text { and long term about the following aspects: coordinate ec } \\
\text { development; invest in intensive technological use; boost pr } \\
\text { to control costs. }\end{array}$ \\
\hline $\begin{array}{l}\text { Planr } \\
\text { welf }\end{array}$ & $\begin{array}{l}\text { Step } 4 \text { of the NDRC, 2010: Apply in a given geographic area pilot projects to } \\
\text { test changes in the industrial system and in the labour market } \\
\text { Step } 5 \text { of the NDRC, 2010: Fill zone development plans to support the } \\
\text { economy according to local needs and opportunities and provide plans for } \\
\text { regional economic cooperation. }\end{array}$ \\
\hline e Minister mı & \\
\hline
\end{tabular}

The commitment of China to coordinate the market is significant, and it is amazing how the Chinese government is able to coordinate and plan the social system, achieving amazing results for economic growth and the establishment of its market-oriented micro global reality spread throughout the world.

Big round of applause has to be recognized the scope for innovation in the reform implemented by Deng Xiaoping that is based on the logic of the Taoist "crossing the river by groping for the stones".

\section{Conclusion}

In the opinion of the writer, Barone's article should not only be appreciated because it is the demonstration that the laws that underpin the capitalist system can be re-imposed at the table and imposed to the real system, to establish a process of socialist market focusing on the rules for researching the highest level of economic welfare; but it must be reassessed as a written that has seen beyond the market systems then known: free trade and collectivism.

The theoretical system outlined by the Italian economist, considered as the result of an eclectic mind, now seems like a hypothesis of a market that has pioneered the times and has proved to be feasible and successful than the capitalism prevailing in the West.

The Asian culture based on eternal principles of a philosophy that seems to have identified the basic ganglia of human behavior have developed a market system which represents a third way between capitalism and collectivism and which has proven to be successful in the international scene.

With this paper we wanted to shed light on a reality that is often underestimated for its ability to revolutionize the existing economic systems that are known not to defend against a devious and deliberately silent economic war.

Willing to conclude with a Chinese saying delivered by China’s economic reformist Deng Xiaoping: "No 
matter whether the cat is black or gray, as long as it catches mice” we can say with certainty that the Asian market has proven to be flexible enough to adapt to the needs of unopposed development without worrying to continue a pattern of ethics and respect for human rights just to "grab" the opportunities of development that the Western capitalism has given to it.

\section{References}

Barone, E. (1888). Lezioni di arte militare. Unpublished.

Barone, E. (1900a). Prefazione. L'iniziativa dei comandanti in guerra. Torino, Italy: Editore F. Casanova.

Barone, E. (1900b). Cun-Nan-Sien. Nuova Antologia.

Barone, E. (1908a). Principi di Economia Politica. Bologna, Italy: Zanichelli.

Barone, E.(1908b). Il Ministro della produzione nello stato collettivista. In Alcuni Studi di Economia Politica. Padova, Italy: Cedam.

Barone, E. (1911). Economia Coloniale. Roma: Tipografia Sabbatini.

Bowles, P., \& White, G. (1994). The political economy of China's financial reforms. Cambridge Journal of Communist Studies and Transition Politics, 10, 80-103.

Chow, G. (1994). Understanding China's economy. New Jersey: World Scientific Publishing Co..

Dorn, J. A. (2001). China's future: Market socialism or market Taoism? Cato Journal, 18(1), 131-146.

Gentilucci, C. E. (2006). L'agitarsi del mondo in cui viviamo. L'economia politica di Enrico Barone. Torino, Italy: Giappichelli.

Herrmann, C., \& Pillath, C. H. (2009). China's path-dependent transition. market and socialism. London: Macmillan.

$\mathrm{Hu}$, X. (1998). Informal property rights and their formalization in 1997. A political economy analysis. China Review, 313-336.

Jing, C. (2001). Sunan Yuyan. Business and Finance Review, 5, 56-125.

Kornai, J., Qian, Y., \& International Economic Association. (2009). Market and socialism: In the light of the experiences of China and Vietnam. Houndmills, Basingstoke, Hampshire, England: Palgrave Macmillan.

Masahiko, A. (2001). Toward a comparative institutional analysis. Stanford University Press.

McCormick, K. (1999). The Tao of Laissez-Faire. Eastern Economic Journal, 25(3), 331-341.

Mini, F. (1998). L'altra strategia. I classici del pensiero militare cinese dalla Guerra al Marketing. Bologna, Italy: Franco Angeli.

Nathan, A., Hong, Z., \& Smith, S. (1999). Dilemmas of reform in Jiang Zemini’s China. London: Edit Rienner Publisher.

Oi, J. C. \& Walder, A. G. (1999). Property Right and Economic Reform in China. Stanford: Press Stanford University.

Petretto, A. (1982). Enrico Barone e i fondamenti della moderna teoria della allocazione delle risorse. In R. Faucci (Ed.), Gli italiani e Bentham. Milano, Italy: Franco Angeli.

Pillath, C. H. (2009). China's path-dependent transition: Culture mediating between market and socialism. Socialism and the market: Conceptual clarification. London: Palgrave.

Rosser, J. B., \& Rosser, M. V. (2004a). Comparative economics in a transforming world economy. Cambridge: MIT Press.

Rosser, J. B., \& Rosser, M. V. (2004b). China's socialist market economy: The sleeping giant wakes. Cambridge: MIT Press.

Sideri, S. (2011). La Cina e gli altri. Nuovi e quilibri della geopolitica. Milano, Italy: ISPI.

Sorrentino, R. (2011, February 2). Sorpresa, il liberismo è Made in Cina. Il Sole 24Ore.

Sulpasso, U. (2010). Darwinomics. Cina USA, Europa e l'economia della conoscenza. Italy: Il Saggiatore.

Tsang, E. W. (1998, May). Can “Guanxi” be a source of sustained competitive advantage for doing business in China? The Academy of Management Executive, 12(2), 64-73.

Vermeer, E. B. (1999). Shareholding cooperatives: A property right analysis. Stanford: Stanford University.

von Hayek, F. A. (1935). Collectivist Economic Planning: Critical Studies on the Possibilities of Socialism. London: Routledge.

$\mathrm{Wu}$, J. (2005). Understanding and interpreting Chinese economic reform. Retrieved from Amazon.com

Wu, J. (2009). Market socialism and Chinese economic reform. Understanding and interpreting Chinese economic reform. London: Palgrave Macmillan.

Yongshu, C. (2003). Collective ownership or cadres' ownership? The non-agricultural use of farmland in China. China Quarterly, $175,662-680$.

Zeng, J. (2005). Cashing out: Survival crises faced by shareholding cooperatives in Shanghai. Asian Perspective, 29(4), 183-208. 